UDC 342.51

DOI: $10.31733 / 2078-3566-2019-5-54-58$

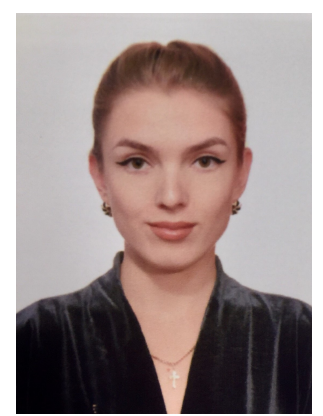

\author{
Anna BYZOVA ${ }^{\odot}$ \\ postgraduate \\ (Dnipropetrovsk State University \\ of Internal Affairs)
}

\title{
LEGAL STATUS OF MILITARY JUSTICE UNDER THE SPECIAL PERIOD AND UNDER CONDITIONS OF CRISIS SITUATIONS THAT THRATEN STATE SECURITY
}

Анна Бизова. ПРАВОВИЙ СТАТУС ВІСБКОВОЇ ЮСТИЦІї В ОСОБЛИВИЙ ПЕРІОД ТА В УМОВАХ КРИЗОВИХ СИТУАЦІЙ, ЩО СТАНОВЛЯТЬ ЗАГРОЗУ НАЦІОНАЛЬНІЙ БЕЗПЕЦІ. У статті проаналізовано законодавство у сфері регулювання правового статусу військової юстиції в Україні. Досліджено поняття «правовий статус», «особливий період», «кризові ситуації, що загрожують національній безпеці». Здійснено розмежування понять «особливий період» та «кризові ситуацій, що загрожують національній безпеці» щодо діяльності органів військової юстиції.

Оголошення рішення про мобілізацію (крім цільової) або доведення його до виконавців стосовно прихованої мобілізації; введення воєнного стану в Україні або в окремих ії місцевостях, що охоплює час мобілізації, воєнний час і частково відбудовний період після закінчення воєнних дій; крайнє загострення протиріч, гостра дестабілізація становища в регіоні, країні, що загрожує державному суверенітету, територіальній цілісності, демократичному конституційному ладу та іншим національним інтересам України визнано як умовами введення режиму особливого періоду, так і ознаками кризової ситуації, що загрожує національній безпеці. Наголошено на консолідації всіх державних органів під час особливого періоду та в умовах виникнення кризових ситуацій, що загрожують національній безпеці.

Констатовано відсутність теоретичних основ та напрацьованих моделей функціонування органів військової юстиції під час особливого періоду та в умовах виникнення кризових ситуацій, що загрожують національній безпеці. Зроблено висновок про необхідність внесення змін у законодавство України з метою закріплення повноважень органів військової юстиції під час особливого періоду та в умовах виникнення кризових ситуацій. Підтримано тезу, що розгляд військової юстиції як лише діяльності військових суддів не дасть об'єктивної можливості всебічно забезпечити розв'язання спорів, захист прав і свобод людини, інтересів підприємств, установ, організацій та держави під час воєнного часу.

Запропоновано розглядати правовий статус органів військової юстиції крізь призму визначення їх завдань, функцій, компетенції і повноважень, форм, методів та цілей діяльності, але 3 урахуванням специфіки, яка притаманна особливому періоду та/або умов кризових ситуацій, що загрожують національній безпеці, що виникла та впливає на відповідну діяльність органів військової юстиції.

Ключові слова: правовий статус; військова юстиція; особливий період; кризові ситуаиіі, щзо загрожують національній безпеці.

Problem statement. State policy in the fields of state security and defense is aimed at the protection of: human and citizen - their lives and dignity, constitutional rights and freedoms, safe living conditions; society - its democratic values, prosperity and conditions for sustainable development; the state - its constitutional order, sovereignty, territorial integrity and inviolability; territory, the environment - from emergencies [1]. Achieving this goal is possible if all public authorities are consolidated, especially during a special period and in the event of crisis situations that threaten national security. Therefore, it is necessary to provide in the legislation for specific powers of state bodies that will act during a special period and in the event of crisis situations that threaten national security, including the prospect of creating a system of military justice.

Due to the armed conflict in the East of Ukraine, military-political instability in the Middle East, the struggle for influence on global financial and energy flows, the increasing militarypolitical instability is increasing. Leading states are increasing the size of military spending, intensifying the development of new weapons, increasing the intensity of military exercises [2].

Therefore, in accordance with the Military Doctrine of Ukraine, the actual military threats to Ukraine are armed aggression and violation of the territorial integrity of Ukraine (temporary occu-

\footnotetext{
(C) Byzova A., 2019

ORCID iD: https://orcid.org/0000-0003-3906-6149

tsp1dduvs@gmail.com
} 
pation by the Russian Federation of the Autonomous Republic of Crimea, the city of Sevastopol and military aggression of the Russian Federation in certain regions of Donetsk and Luhansk regions). Federation in close proximity to the state border of Ukraine, including the potential deployment of tactical nuclear weapons on the territory of the Autonomic Republic of Crimea [2].

In such circumstances, there are events that do not fall under the existing classification of emergencies where there is a threat to national security and no actual hostilities. This situation should be attributed to crisis situations that threaten national security or a "special" period that precedes an emergency. In such circumstances, it is necessary to intensify preventive measures aimed at improving the system of interaction of public authorities during a special period and crisis that threatens national security. Particularly urgent is the issue of the creation of military justice as a system of bodies with powers sufficient to respond effectively and adequately to external threats. Thus, in the face of further aggression by the Russian Federation, the study of the legal status of military justice bodies becomes especially relevant.

Analysis of publications that started solving this problem. It is important to note that, despite the exceptional importance and relevance of the issue of the legal status of military justice bodies during the special period and in the event of crisis situations that threaten national security, domestic and foreign science did not pay sufficient attention to the development of its theoretical foundations. The absence of definitions, adequate conceptual apparatus indicates significant gaps in the current legislation of Ukraine.

At the same time, despite the considerable theoretical basis of the military justice research, the legal status of the military justice bodies during the special period and in the event of crisis situations that threaten national security is not determined at the legislative or scientific level.

The article's objective. Given the relevance and significance of the problem, the purpose of the article is to determine the legal status of military justice authorities during a special period and in the event of a crisis that threatens national security.

To achieve this goal were set the following tasks:

- to determine the essence and normative content of the concept of legal status of military justice;

- to consider and analyze the concepts of special period and crisis situations that threaten national security;

- to determine the powers of the military justice authorities during the special period and in the event of crisis situations that threaten national security.

Basic content. The issue of defining the term "legal status of a state body" in the scientific literature is ambiguous.

Mr. Kulish A.M. notes that the issue of the legal status of a state body in the legal literature has until recently been reduced mainly to the definition of its competence, established by the legislation of a circle of rights and duties, which does not fully reveal the meaning of the concept of "legal status". The legal status of a state body, as a rule, means a certain set of powers of a juridical authority, the implementation of which ensures the fulfillment of the tasks assigned to it. But O.M. Mr.Bandurka O.M. warns that such a definition is rather narrow, it does not cover much of the issues of organization and activity of state bodies that determine their legal status or status (these two concepts are often identified, regarded as synonymous) [3]. Therefore, NV. The swan defines legal status as a set of four basic elements: the target (includes rules on the purpose, objectives, functions, principles of activity); organizational (contains legal regulations governing the order of creation, reorganization and liquidation of the body; organizational structure; the procedure for appointment to the position of head, etc.); competences; responsibility [4, p. 38].

Thus, the legal status of military justice bodies must determine their tasks, functions, competences and powers, forms, methods and objectives of activity, but taking into account the specificities inherent in the specific period and / or conditions of crisis that threaten national security and influences the activities of military justice bodies.

Justice can be seen narrowly as a system of judicial institutions, or broadly as a collection of judicial and executive authorities whose activities are aimed at resolving disputes, securing human rights and freedoms, protecting its interests, the interests of enterprises, institutions, organizations and the state.

In our view, consideration of military justice as a mere activity of military judges will not give an objective opportunity to comprehensively ensure the resolution of disputes, the protection of human rights and freedoms, the interests of enterprises, institutions, organizations and the state during wartime.

Considering all of the above in the system of military justice, in the broadest sense, may 
include military courts, the State Bureau of Investigation (military prosecutor's office or state bureau of military justice), military police, military advocacy, legal service of military units. It is the activity of these bodies that should be regulated by law, including the legal status of military justice during a special period and crisis situations that threaten national security. But now, military justice is in the making, so determining the legal status of military justice during a special period and crisis situations that threaten national security requires legislation before it is adopted.

It is also important to distinguish between "special period" and "crisis situations that threaten national security". Thus, the Law of Ukraine "On Mobilization Training and Mobilization" defines a special period as the period of functioning of the national economy, state authorities, other state bodies, local self-government bodies, the Armed Forces of Ukraine, other military formations, civil defense forces, enterprises, institutions and organizations, as well as the fulfillment by the citizens of Ukraine of their constitutional obligation to protect the Motherland, independence and territorial integrity of Ukraine, which comes from the moment of the announcement of the mobilization decision (to target them) or bring it to the performers regarding mobilization or hidden since the introduction of martial law in Ukraine or in its particular areas and covers the period of mobilization, and wartime partial recovery period after the end of hostilities. [5] Law about the Defense of Ukraine asperiod, which comes from the moment of announcement of the decision to mobilize (other than the targeted one) or to bring it to the executors for concealed mobilization or from the moment of entering martial law in Ukraine or in some of its localities and covers the time of mobilization, wartime and partially rebuilding period after the end of hostilities [6].

The concept of crisis is defined in the legislative acts, depending on the area in which it is applied. Thus, in international relations, the crisis situation is a set of military-political and social conflicts that destabilize the situation on the external border and require collective measures to stabilize it [7]; in the field of nuclear security, crisis situation - a situation which may or may arise as a result of the perpetration or threat of committing a sabotage, theft or any other unlawful removal of nuclear materials [8]; in the field of civil aviation security, a crisis situation is a situation committing unlawful and deliberate acts related to the encroachment on normal, regular and safe civil aviation activities, causing accidents with people, property damage, acts of unlawful interference or creating a real LU these effects [9], in the social sphere, the crisis - a situation in which there is a set of traumatic events and circumstances from which people cannot go out without changing them. The number of options to change these circumstances is insignificant, any attempt to change the circumstances in the traditional or usual ways can lead to a worsening of the situation, a reduction of opportunities and an even greater limitation of actions [10]; in national security - crisis situation is considered the extreme aggravation of contradictions, acute destabilization of the situation in any sphere of activity, region, country [11].

The crisis situation should threaten the national security of Ukraine, under which the Law of Ukraine "On National Security of Ukraine" means the protection of state sovereignty, territorial integrity, democratic constitutional order and other national interests of Ukraine against real and potential threats [1].

Thus, the crisis situation that threatens national security is the extreme aggravation of contradictions, acute destabilization of the situation in the region, a country that threatens state sovereignty, territorial integrity, democratic constitutional order and other national interests of Ukraine.

Summarizing the above, the introduction of a special period or the emergence of a crisis situation that threatens national security provides:

- announcement of the decision on mobilization (other than the targeted one) or bringing it to the executors regarding hidden mobilization;

- the introduction of martial law in Ukraine or in some of its localities, covering the time of mobilization, wartime and the partially rebuilding period after the end of hostilities;

- extreme aggravation of contradictions, acute destabilization of the situation in the region, the country, which threatens state sovereignty, territorial integrity, democratic constitutional order and other national interests of Ukraine.

If the legislation of Ukraine provides for the concept of a special period, crisis situations, then it is necessary to make amendments to the normative-legal acts that regulate the activity of state bodies, taking into account the specific nature of such situations. This is especially true of military justice authorities, which should have additional powers during such periods. For example, the draft law "On the State Bureau of Military Justice" provides that, in the event of the introduction of a martial law or a state of emergency in Ukraine or in certain localities and the occurrence of a special period, the State Police Military Police:

1) take part in the fight against sabotage groups and illegal armed groups; 
2) organize the activities of military commanders;

3) participate in the organization of gathering and support of prisoners of war;

4) take part in ensuring that the curfew is observed in garrisons;

5) control the movement of vehicles and the transportation of their goods [12].

Such articles should be provided in normative legal acts that will regulate the legal status of military police, military courts, military advocacy, legal service of military units. First and foremost, this concerns a key element of the legal status - power, that is, additional powers that arise during a special period and in situations of crisis that threaten national security. Also, a special period and crisis that threatens the national security of Ukraine may provide for a separate procedure for the functioning, establishment and subordination of military justice bodies.

Currently, in a state of martial law or emergency, in a special period, as well as in case of crisis situations that threaten the national security of Ukraine, the National Security and Defense Council of Ukraine coordinates the activities of executive authorities, considers proposals for the application of special economic and other restrictive measures [1].

The National Security and Defense Council of Ukraine, in accordance with the Constitution of Ukraine, is the coordinating body for national security and defense under the President of Ukraine [11].

According to the Law of Ukraine "On National Security of Ukraine", the security and defense sector of Ukraine consists of four interrelated components: security forces; defense forces; defense-industrial complex; citizens and civic associations voluntarily involved in national security. The functions and powers of the components of the security and defense sector are determined by the legislation of Ukraine [1].

The security and defense sectors include: Ministry of Defense of Ukraine, Armed Forces of Ukraine, State Special Transport Service, Ministry of Internal Affairs of Ukraine, National Guard of Ukraine, National Police of Ukraine, State Border Service of Ukraine, State Migration Service of Ukraine, State Emergency Service of Ukraine, Security Service of Ukraine, State Security Service of Ukraine, State Service for Special Communications and Information Protection of Ukraine, Apparatus of the National Security and Defense Council of Ukraine, the intelligence agencies of Ukraine, the central executive authority that provides for the formation and implementation of state military-industrial policy [1].

Other state and local self-government bodies perform their national security functions in cooperation with the bodies belonging to the security and defense sector [1].

Therefore, the Law "On National Security of Ukraine" defines only the legal status of the National Police of Ukraine as a central body of executive power, providing public security and order, protection of human rights and freedoms, interests of society and the state, combating crime, as well as providing legal assistance services persons who, for personal, economic, social or emergency reasons, need such assistance. The activities of the National Police of Ukraine are directed and coordinated by the Cabinet of Ministers of Ukraine through the MIA of Ukraine [1].

Conclusions and prospects for further scientific research. According to the realities in Ukraine, there are more and more threats to the state security. Therefore, a system of state facilities that would satisfy society in peacetime is not sufficiently effective during a special period and in case of crisis situations that threaten state security. Such a mechanism of the state needs modernization, adjustment to new circumstances by amending the existing legislation or creating radically new norms that will start strengthening the rule of law and democratic state of Ukraine.

References:

1. Про національну безпеку: Закон України від 21.06. 2018 p. № 2469-VIII. URL: https://zakon.rada.gov.ua/laws/show/2469-19.

2. Про рішення Ради національної безпеки та оборони України від 2 вересня 2015 р. «Про нову редакцію Військової доктрини України»: Указ Президента України від 24 вересня 2015 р. № 555/2015. URL: https://zakon.rada.gov.ua/laws/show/555/2015.

3. Матеріал Вікіпедії - вільної енциклопедії. Правовий статус. URL: https: //en.wikipedia.org/wiki/\%D0\%9F\%D1\%80\%D0\%B0\%D0\%B2\%D0\%BE\%D0\%B2\%D0\%B8\%D0\%B9 \%D1\%81 \% D1\% 82\% D0\% B0\% D1\% 82\% D1\% 83\% D1\% 81

4. Лебедь Н. В. Адміністративно-правовий статус державних інспекцій в Україні: дис. канд. юрид. наук: 12.00.07 / Нац. ун-т. внутр. справ. Харків, 2004. 185 с.

5. Про мобілізаційну підготовку та мобілізацію: Закон України від 21 жовтня 1993 р. №3543-XII. URL: https: //zakon.rada.gov.ua/laws/show/3543-12 (доступ до 11.11.2019).

6. Про оборону України: Закон України від 06.12.1991 № 1932-XII. URL: https: //zakon.rada.gov.ua/laws/show/1932-12.

7. Рішення щодо проекту Угоди про взаємодію прикордонних військ держав-учасниць Співдружності Незалежних Держав у разі надзвичайних криз на зовнішніх кордонах від 12.04.1996. URL: https://zakon.rada.gov.ua/laws/show/997_c29/ed19960412/find?text=\%CA\%F0\%E8\%E7\%EE\%E2\%E0+\%F1\% $\mathrm{E} 8 \% \mathrm{~F} 2 \% \mathrm{~F} 3 \% \mathrm{E} 0 \% \mathrm{~F} 6 \% \mathrm{~B} 3 \% \mathrm{FF}$. 
8. Про затвердження Загальних вимог до систем фізичного захисту ядерних установок та ядерних матеріалів та Загальних вимог до систем фізичного захисту ядерних матеріалів під час їх транспортування: Наказ Державного комітету з ядерного регулювання від 28.08.2008 N 156. URL: https: //zakon.rada. gov.uallaws/show/z099908/ed20081101/find?text=\%CA\%F0\%E8\%E7\%EE\%E2\%E0+\%F1\%E8\%F2\%F3\%E0\%F6\%B3\%FF.

9. Про Державну програму авіаційної безпеки цивільної авіації: Закон України від 21.03.2017 p. № 1965-VIII. URL: https://zakon.rada.gov.ua/laws/show/1965-19\#n717.

10. Про затвердження Державного стандарту соціальних служб кризових ситуацій та надзвичайних ситуацій: наказ Міністерства соціальної політики від 7 липня 2016 року № 716 . URL: https://zakon.rada.gov.ua/laws/show/ z0990-16 / ed20160701 \# n24.

11. Про Раду національної безпеки і оборони України: Закон України від 05.03.1998 № 183/98-BP. URL: https://zakon.rada.gov.ua/laws/show/183/98-\%D0\%B2\%D1\%80.

12. Про Державне бюро військового правосуддя: законопроект 8387 від 21.05.2018. URL: http://w1.c1.rada.gov.ua/pls/zweb2/webproc4_2?pf3516=8387\&skl=9.

Received to editorial board 25.11.2019

1. Pro natsional'nu bezpeku [On National Security]: Zakon Ukrayiny vid 21.06. 2018 r. № 2469VIII. URL: https://zakon.rada.gov.ua/laws/show/2469-19. [in Ukr.]

2. Pro rishennya Rady natsional'noyi bezpeky ta oborony Ukrayiny vid 2 veresnya 2015 r. «Pro novu redaktsiyu Viys'kovoyi doktryny Ukrayiny» [On the decision of the National Security and Defense Council of Ukraine of 2 September 2015 "On the new version of the Military Doctrine of Ukraine"]: Ukaz Prezydenta Ukrayiny vid 24 veresnya 2015 r. № 555/2015. URL: https://zakon.rada.gov.ua/laws/show/555/2015. [in Ukr.]

3. Material Vikipediyi - vil'noyi entsyklopediyi. Pravovyy status [Wikipedia material - free encyclopedia. Legal Status]. URL: https: //en.wikipedia.org/wiki/\%D0\%9F\%D1\%80\%D0\%B0\%D0\%B2\%D0\%BE\%D0\%B2\%D0\%B8\%D0\%B9 $\% \mathrm{D} 1 \% 81 \% \mathrm{D} 1 \%$ 82\% D0\% B0\% D1\% 82\% D1\% 83\% D1\% 81. [in Ukr.]

4. Lebed' N. V. Administratyvno-pravovyy status derzhavnykh inspektsiy v Ukrayini [Administrative-legal status of state inspections in Ukraine]: dys. kand. yuryd. nauk: 12.00.07 / Nats. un-t. vnutr. sprav. Kharkiv, 2004. 185 s. [in Ukr.]

5. Pro mobilizatsiynu pidhotovku ta mobilizatsiyu [On mobilization training and mobilization]: Zakon Ukrayiny vid 21 zhovtnya 1993 r. №3543-XII. URL: https: //zakon.rada.gov.ua/laws/show/354312 (dostup do 11.11.2019). [in Ukr.]

6. Pro oboronu Ukrayiny [On the defense of Ukraine]: Zakon Ukrayiny vid 06.12.1991 № 1932XII. URL: https: //zakon.rada.gov.ua/laws/show/1932-12. [in Ukr.]

7. Rishennya shchodo proektu Uhody pro vzayemodiyu prykordonnykh viys'k derzhav-uchasnyts' Spivdruzhnosti Nezalezhnykh Derzhav u razi nadzvychaynykh kryz na zovnishnikh kordonakh vid 12.04.1996 [Decision on the draft Agreement on the Interaction of Border Troops of the States Parties to the Commonwealth of Independent States in case of Emergency Crises on the External Borders of 12.04.1996]. URL: https://zakon.rada.gov.ua/laws/show/997_c29/ed19960412/find?text=\%CA\%F0\%E8\%E7\%EE\%E2\%E0+ $\% \mathrm{~F} 1 \% \mathrm{E} 8 \% \mathrm{~F} 2 \% \mathrm{~F} 3 \% \mathrm{E} 0 \% \mathrm{~F} 6 \% \mathrm{~B} 3 \% \mathrm{FF}$. [in Ukr.]

8. Pro zatverdzhennya Zahal'nykh vymoh do system fizychnoho zakhystu yadernykh ustanovok ta yadernykh materialiv ta Zahal'nykh vymoh do system fizychnoho zakhystu yadernykh materialiv pid chas yikh transportuvannya [On approval of the General requirements for the physical protection systems of nuclear installations and nuclear materials and the General requirements for the physical protection systems of nuclear materials during their transportation]: Nakaz Derzhavnoho komitetu z yadernoho rehulyuvannya vid 28.08.2008 N 156 . URL: https: I/zakon.rada. gov.ua/laws/show/z099908/ed20081101/find?text $=\% \mathrm{CA} \% \mathrm{~F} 0 \% \mathrm{E} 8 \% \mathrm{E} 7 \% \mathrm{EE} \% \mathrm{E} 2 \% \mathrm{E} 0+\% \mathrm{~F} 1 \% \mathrm{E} 8 \% \mathrm{~F} 2 \% \mathrm{~F} 3 \% \mathrm{E} 0 \% \mathrm{~F} 6 \% \mathrm{~B} 3 \% \mathrm{FF}$. [in Ukr.]

9. Pro Derzhavnu prohramu aviatsiynoyi bezpeky tsyvil'noyi aviatsiyi [On the State Aviation Security Program for Civil Aviation]: Zakon Ukrayiny vid 21.03.2017 r. № 1965-VIII. URL: https://zakon.rada.gov.ua/laws/show/1965-19\#n717. [in Ukr.]

10. Pro zatverdzhennya Derzhavnoho standartu sotsial'nykh sluzhb kryzovykh sytuatsiy ta nadzvychaynykh sytuatsiy [On approval of the State Standard for Social Services of Crisis and Emergency Intervention]: nakaz Ministerstva sotsial'noyi polityky vid 7 lypnya 2016 roku № 716 . URL: https://zakon.rada.gov.ua/laws/show/ z0990-16 / ed20160701 \# n24. [in Ukr.]

11. Pro Radu natsional'noyi bezpeky i oborony Ukrayiny [On the National Security and Defense Council of Ukraine]: Zakon Ukrayiny vid 05.03.1998 № 183/98-VR. URL: https://zakon.rada.gov.ua/laws/show/183/98-\%D0\%B2\%D1\%80. 12. Pro Derzhavne byuro viys'kovoho pravosuddya: $\quad$ zakonoproekt $\quad 8387 \quad$ vid $\quad 21.05 .2018 . \quad$ URL: http://w1.c1.rada.gov.ua/pls/zweb2/webproc4_2?pf3516=8387\&skl=9. [in Ukr.]

12. Pro Derzhavne byuro viys'kovoho pravosuddya [On the State Bureau of Military Justice]: za8387 vid 21.05.2018

http://w1.c1.rada.gov.ua/pls/zweb2/webproc4_2?pf3516=8387\&skl=9. [in Ukr.]

\section{Summary}

The article analyzes the legislation in the field of regulation of the legal status of military justice in Ukraine. The concepts of "legal status", "special period", "crisis situations that threaten national security" are investigated. The conclusion was made about the necessity of amending the legislation of Ukraine in order to consolidate the powers of the military justice authorities during a special period and in crisis situations.

Keywords: legal status, military justice, special period, crisis situations that threaten state security. 